Jurnal Teknologi Laboratorium

Vol.9, No.1, Special Edition 2020, pp. $49-57$

ISSN 2580-0191(Online), ISSN 2338 - 5634(Print)

DOI: 10.29238/teknolabjournal.v9i1.222

Journal homepage: https://www.teknolabjournal.com/index.php/Jt//index

Article Review

\title{
Diagnosis and epidemiology of Coronavirus (COVID-19) outbreak in Indonesia
}

\author{
Sutaryono ${ }^{1 a^{*}}$, Sholikhah Deti Andasari ${ }^{1 \mathrm{~b}}$, Heru Subaris Kasjono ${ }^{2 \mathrm{c}}$ \\ ${ }^{1}$ Department of Pharmacy, Sekolah Tinggi Ilmu Kesehatan Muhammadiyah Klaten, Indonesia \\ 2 Poltekkes Kemenkes Yogyakarta, Indonesia \\ aE-mail address : sutaryono@stikesmukla.ac.id \\ bE-mail address : deti@stikesmukla.ac.id \\ cE-mail address : heru.subarisk@poltekkesjogja.ac.id
}

HIGHLIGHTS

- $\quad$ Patients diagnosed were aged 30-49 years

- Highest comorbidity are hypertension, diabetes mellitus and cardiac disease

- Large-scale Social Restrictions or "Pembatasan Sosial Berskala Besar (PSBB)" policy

\section{ARTICLE INFO}

\section{Article history}

Received Date: May 04, 2020

Revised Date: June 04, 2020

Accepted Date: July 02, 2020

\section{Keywords:}

Covid-19

PSBB

Coronavirus

Epidemiology

Outbreak

\section{A B S T R A C T}

COVID-19 has experienced an increase in 2,995,758 positive cases and 204,987 deaths, in distribution areas of more than 213 countries. This research using a systematic literature review, policy brief and internet-based questionnaire with the aim of finding out the diagnosis and epidemiology of Coronavirus (COVID-19) outbreak in Indonesia. The cases in Indonesia have reached 9,771 and killed 784 people, possibly as many as of 19 cases are asymptomatic but can be carriers of the virus. The diagnosis is carried out by rapid testing and using a polymerase chain reaction (PCR). Most of the patients diagnosed were aged 30-49 years (38.91\%), the highest accompanying diseases were hypertension $(34.85 \%)$, diabetes mellitus $(25.76 \%)$ and cardiac disease $(17.05 \%)$. The most signs and symptoms are that the patient has a cough, shortness of breath and has a history of internal medicine and fever. Based on sex mostly experienced by men (58.94\%) compared to women (41.06\%). The Government of Indonesia is making efforts to reduce the COVID-19 outbreak by implementing a health protocol and a Large-scale Social Restrictions or "Pembatasan Sosial Berskala Besar (PSBB)" policy.

*Corresponding Author:

Sutaryono

Department of Pharmacy, Sekolah Tinggi IImu Kesehatan Muhammadiyah Klaten, Indonesia

Email: sutaryono@stikesmukla.ac.id

Phone: +62858-7941-4066 


\section{INTRODUCTION}

Coronavirus outbreak occurred in the world Since mid-December 2019. This disease was first discovered in Wuhan City, Hubei, China, which is found in Wuhan's Huanan Seafood Wholesale Market or a market of fish and live animals that sell various species of animals. ${ }^{1}$ It has been reported that this disease is caused by SARS-CoV-2 (formerly 2019-nCoV or HCoV19). In general, the incubation period is 1 to 14 days (average: 5-6 days) but can reach 92 for 24 days. $^{2}$ The most commonly seen characteristics of COVID-19 are fever, cough and abnormal chest computed tomography (CT). ${ }^{3}$ On Feb 11, 2020, The World Health Organization (WHO) declared a 2019 coronavirus disease (Covid-19) as a pandemic. To date Apr 29, 2020, COVID-19 has experienced an increase in cases of 2,995,758 positive and 204,987 died. Spread areas occur in more than 213 countries including Indonesia, this is a

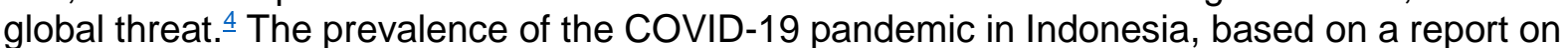
Apr 29, 2020, showed an increase in cases, of which 9,771 were positive, 1,391 recovered and 784 died. $^{5}$

This disease appears inseparable from the role of animals or zoonoses in transmission to humans, bats, anteater and dogs that are suspected to be their hosts. ${ }^{6,7}$ Human to human transmission from Covid-19 occurs mainly through respiratory droplets, direct contact, asymptomatic transmission, and intrafamilial transmission. ${ }^{2,8}$

COVID-19 can affect any demographics, including old age, children, and pregnant women. Therefore to stop transmission of the virus and save the lives of its citizens, the Indonesian government implements strategies and tactics including protocol directives from the World Health Organization (WHO) such as free testing with rapid tests and PCR, free treatment, the establishment of COVID-19 hospitals, large-scale social restrictions, and volunteering and involving social organizations to handle this pandemic.

To see an overview of the outbreak and management of COVID-19 handling in Indonesia, there needs to be an epidemiological study based on data reports from various sources, especially the Task Force for the Acceleration of Handling COVID-19 from the Ministry of Health of the Republic of Indonesia and a review of articles from various available sources and references. It is hoped that this study will be able to explain the understanding of COVID-19, which causes high mortality rates and suggest developing strategies to overcome future epidemic threats.

\section{REVIEW METHOD}

A narrative review was conducted using Elsevier, Medline / PubMed, Scopus, and Web of Science. The search terms use keywords: "Novel coronavirus," "Novel coronavirus 2019", "2019 nCoV", "Covid-19", "diagnosis". Observation studies and case reports for calculating prevalence were obtained from the policy brief and the report of the Task Force for the Acceleration of COVID-19 Handling of the Ministry of Health of the Republic of Indonesia. We also presented a survey policy brief to assess compliance with the physical, social distancing of the Research and Development Center for Humanities and Health Management, Litbang RI online (internet, Facebook, Instagram, Twitter, WhatsApp) 19.654 respondents spread in 34 provinces in Indonesia.

\section{RESULTS AND DISCUSSION}

\section{Pathogenesis}

Coronavirus 2019 is an inflammatory lung parenchymal disease caused by severe acute respiratory syndrome coronavirus 2 (SARS-CoV-2). Clinical symptoms that arise vary from shock without complications (mild) to septic (severe)., , 10 Coronavirus is the only positive RNA virus, which is encapsulated, not segmented. There are four genera, namely alpha coronavirus, betacoronavirus, deltacoronavirus and gamma coronavirus. Severe respiratory failure in COVID-19 is commonly associated with the hyperinflammatory syndrome. Cytokine storms may cause hyper inflammation in severe SARSCoV-2 disease. .11

Coronaviruses have capsules, round or elliptical particles, often pleomorphic with diameters of around 50-200 $\mathrm{nm}$ and coronavirus structures form cube-like structures with 
protein $S$ located on the surface of the virus. ${ }^{12,13}$ The envelope is studded with projecting glycoproteins and surrounds a core consisting of matrix protein enclosed within which is a single strand of positive-sense RNA $\left(\mathrm{Mr} 6 \times 10^{6}\right)$ associated with nucleoprotein. The envelope glycoproteins are responsible for attachment to the host cell and also carry the main antigenic epitopes, particularly the epitopes recognized by neutralizing antibodies. OC43 also possesses a haemagglutinin.

Coronavirus is sensitive to heat and can effectively be activated by disinfectants containing chlorine, lipid solvents with a temperature of $56{ }^{\circ} \mathrm{C}$ for 30 minutes, ether, alcohol, peroxyacetic acid, non-ionic detergents, formalin, oxidizing agents and chloroform. Chlorhexidine is not effective in deactivating the virus. Coronavirus infections usually occur frequently in winter and humidity is not too high. ${ }^{12,13}$

This new type of Coronavirus pneumonia can occur in all people, especially immunocompromise. If exposed to large amounts of the virus at one time, can cause disease even though the body's immune system is functioning normally. People with weak immune systems such as the elderly, pregnant women, and other conditions, can cause the disease progressively faster and more severely. Coronavirus infection causes a weakened immune system against this virus so re-infection can occur. ${ }^{12,13}$

The main clinical symptoms of COVID-19 infection are fever (temperature $>38^{\circ} \mathrm{C}$ ), cough and difficulty breathing. Moreover, it can be accompanied by heavy tightness, fatigue, myalgia, gastrointestinal symptoms such as diarrhoea and other respiratory symptoms. In some patients, mild symptoms are not accompanied by fever. ${ }^{12,13}$ Besides, fever and cough are reported to be the most common symptoms associated with COVID-19 patients. $\frac{3}{}$ However, mild symptoms such as nausea, headaches, respiratory problems, sore throat, myalgia, vomiting and sometimes diarrhoea were also shown in COVID-19 patients. ${ }^{3,14}$

A meta-analysis study from journals concluded that COVID 19 patients would be exacerbated by comorbidities including was fever ( $91 \pm 3,95 \% \mathrm{Cl} 86-97 \%)$, followed by cough $(67 \pm 7,95 \% \mathrm{Cl} 59-76 \%)$, fatigue $(51 \pm 0,95 \% \mathrm{Cl} 34-68 \%)$ and dyspnea $(30 \pm 4,95 \% \mathrm{Cl} 21-$ $40 \%)$. The most prevalent comorbidities were hypertension (17 $\pm 7,95 \% \mathrm{Cl} 14-22 \%)$ and diabetes $(8 \pm 6,95 \% \mathrm{Cl} 6-11 \%)$, followed by cardiovascular diseases $(5 \pm 4,95 \% \mathrm{Cl} 4-7 \%)$ and respiratory system disease $(2 \pm 0,95 \% \mathrm{Cl} 1-3 \%)$. Compared with the Non-severe patient, the pooled odds ratio of hypertension, respiratory system disease, cardiovascular disease in severe patients were (OR 2.36, 95\% Cl: 1.46-3.83), (OR 2.46, 95\% Cl: 1.76-3.44) and (OR $3.42,95 \% \mathrm{Cl}: 1.88-6.22)$ respectively. ${ }^{15}$

The spread of the virus can be through close contact, environment or objects contaminated with the virus, airway droplets, and airborne particles. A droplet is particlecontaining water with a diameter of $>5 \mathrm{um}$. Droplets can pass up to a certain distance (usually 1 meter) to the vulnerable mucosal surface. Droplet particles are large enough so that they will not last or settle in the air for a long time. Droplet production from the airways includes coughing, sneezing or talking as well as invasive respiratory procedures such as sputum aspiration or bronchoscopy, tracheal tube insertion. Airborne particles are particles with a diameter of less than 5um, which can spread over long distances and are still infectious. Airborne pathogens can spread by contact. Direct contact is the transmission of pathogens directly with the skin or mucous membranes, blood or blood fluid that enters the body through mucous membranes or damaged skin. ${ }^{12,13}$

\section{Diagnosis}

Laboratory markers of disease progression and clinical outcomes, such as D-dimer, C-Reactive Protein (CRP), procalcitonin, neutrophil count, lymphocyte count and inflammatory cytokines were monitored. ${ }^{2,11}$ Regarding laboratory findings, decreased albumin $(75.8 \%$, $95 \% \mathrm{Cl} 30.5-100.0 \%)$, high C-reactive protein $(58.3 \%, 95 \% \mathrm{Cl} 21.8-94.7 \%)$, and high lactate dehydrogenase (LDH) $(57.0 \%, 95 \% \mathrm{Cl} 38.0-76.0)$, lymphopenia $(43.1 \%, 95 \% \mathrm{Cl} 18.9-67.3)$, and high erythrocyte sedimentation rate (ESR) $(41.8 \%, 95 \% \mathrm{Cl} 0.0-92.8)$, were the most prevalent laboratory results (Morales, 2020). Diagnostic tests for COVID-19 have been developed such as reverse transcription-polymerase chain (RT-PCR), real-time PCR, real-time quantitative RT-PCR (rRTqPCR), COVID-19-RdRp/Hel real-time RT-PCR assay, 
POCT/bedside testing, loop-mediated isothermal amplification (RT-LAMP), full genome analysis by next-generation sequencing (NGS), fluorescence-based quantitative PCR assay, enzyme-linked immunosorbent assay (ELISA), computed tomography technique (CT) imaging and X-Ray. ${ }^{9,16,17}$

Histologically, tissue biopsy of the lungs, liver and heart tissue reveals pneumococcal desquamation, hyaline membrane formation, diffuse bilateral alveolar damage in conjunction with cellular fibromyxoid exudates. Multiple nucleated syncytial cells, atypical enlarged pneumocytes, interstitial mononuclear inflammatory infiltrates along with the presence of the majority of lymphocytes in the affected lung configuring significant cytopathic effects. ${ }^{11}$ Nearly all COVID-19 patients are reported to have varying degrees of disability in lung pneumonia with other viruses on CT imaging. In addition, other findings include bilateral multilobular sublateral consolidation of the lungs at an early stage followed by multiple mottling and groundglass opacity. 9,11

Severe pulmonary lesions are seen around the 10th day after initial symptoms in most patients recovering from COVID-19 disease..$^{18}$ The blood profile of COVID-19 patients showed lymphopenia, leukopenia, thrombocytopenia and anaemia, along with higher aspartate aminotransferase levels and hypersensitive troponin. ${ }^{9,11}$ Initially reported to be normal, but a slight increase in level in the later stages was noted, indicating the possibility of secondary infection. ${ }^{11}$ Cytokine storm associated with the rampant inflammation resulted into the release of proinflammatory cytokines and chemokines like IFN- $\gamma$, IL-1 $\beta$, IP-10, MCP-1, TNF- $\alpha$, GCSF, MCP-1, IP-10, and MIP-1A which severely damages pulmonary tissues leading to death in severe COVID-19 patients. Although, lymphopenia, leucopenia, thrombocytopenia, and RNAaemia occurs with a decrease in helper T cells, regulatory $T$ cells, and memory $T$ cells in severe COVID-19 cases notably the levels of Th1 and Th2 cytokines are found elevated. However, elevated levels of ALT, AST, LDH, CPK, creatinine, $\mathrm{\gamma}-\mathrm{GT}$ and $\alpha-\mathrm{HBDH}$ in a severe form of the disease suggests multiorgan involvement. ${ }^{16}$

\section{COVID-19 Epidemiology in Indonesia}

On April 28, 2020, Data from World Health Organization (WHO), there were 2,954,222 positive COVID-19 cases and 202,597 dead, spreading over 213 countries. Cases in several countries show European Region 1,386,693 confirmed (27,313) 126,429 deaths $(1,904)$, Region of the Americas 1,179,607 confirmed $(39,087) 60,211$ deaths $(1,722)$, Eastern Mediterranean Region, 171,238 confirmed (5,305), 7,148 deaths (157), Western Pacific Region 145,385 confirmed (1,264) 5,998 deaths (40), South-East Asia Region 48,348 confirmed (2,288) 1,917 deaths (93) African Region, 22,239 confirmed (769) 881 deaths. ${ }^{19}$

The official statistics of the epidemic in Indonesia were reported by the Ministry of Health through the Task Force for the Acceleration of Handling COVID-19, 2020, on Apr 29, 2020, the cumulative number of positive cases was 9,771 recovered 1,391 and 784 people died (cluster/web). Figure 1 shows the distribution of confirmed cases ${ }^{5}$ in April 2020.

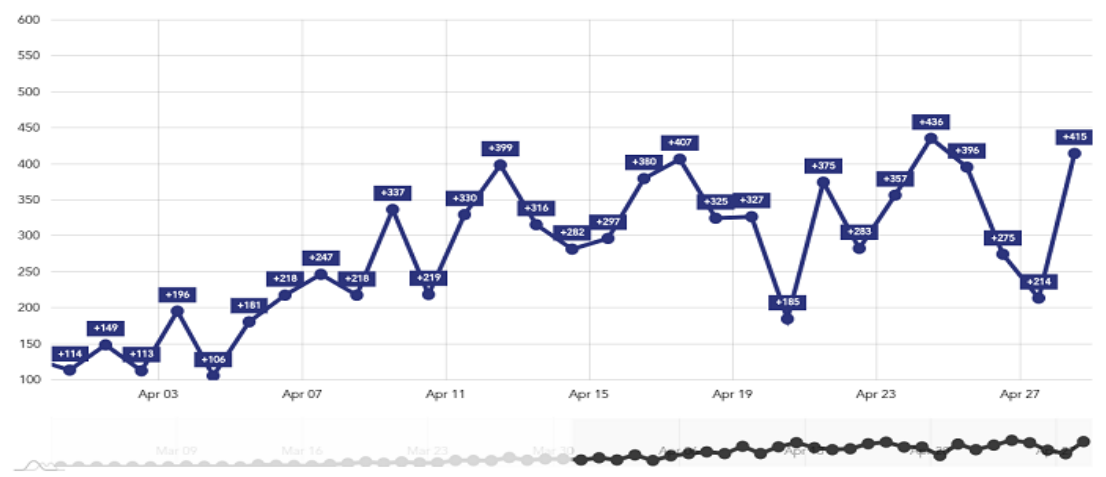

Figure.1 Distribution of Confirmed Cases during April 2020 in Indonesia 5

At the beginning of April, there were 114 confirmed cases, further increasing until the second week, there were 407 cases. Fluctuations occurred from the third week to the 
fourth week and even dropped by only 214 cases, but the next day there was an increase again. Starting at the end of the month, the fluctuation case has begun to stabilize or decrease, and this is due to the Indonesian government making policies with large-scale social restrictions. The number of COVID-19 cases above is substantially possible still below proportion because the data are only based on rapid tests or by polymerase chain reaction (PCR) while many people have not been confirmed even though they have the potential to be carriers of asymptomatic viruses. It has been speculated that the total number of COVID-19 infected people is about five times higher than the official statistics. This bias must be taken into account when interpreting any COVID-19 statistics. ${ }^{20}$

The distribution of the COVID-19 case area almost occurred in all provinces in Indonesia, the highest being in DKI Jakarta, West Java, East Java, Central Java, followed by other provinces. The age of COVID-19 patients in Indonesia who had been diagnosed was mostly $30-49$ years $(38.91 \%)$, seen in figure 2 .

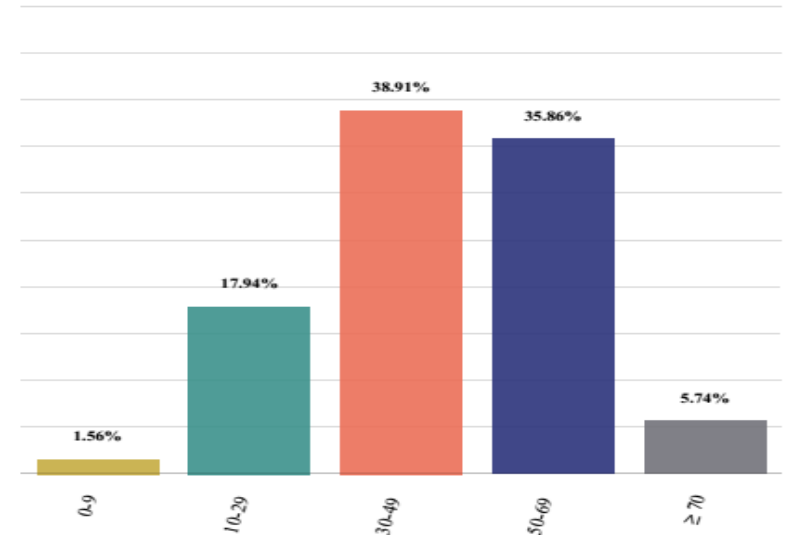

Figure 2. Distribution of COVID-19 Cases By $\mathrm{Age}^{\underline{5}}$

Figure 2 shows that many cases of COVID-19 death are experienced in older people; this is associated with a weak immune system that allows faster development of viral infections and comorbidities..$^{21,22}$ The results of previous studies, most patients heal themselves, while the mortality rate is around $10-14 \%$, especially patients over the age of 40 years with comorbidities such as heart disease, asthma, chronic lung disease and diabetes. ${ }^{21}$ The highest incidence of COVID-19 with comorbidities in Indonesia was hypertension (34.85\%), diabetes mellitus (25.76\%) and cardiac disease (17.05\%).

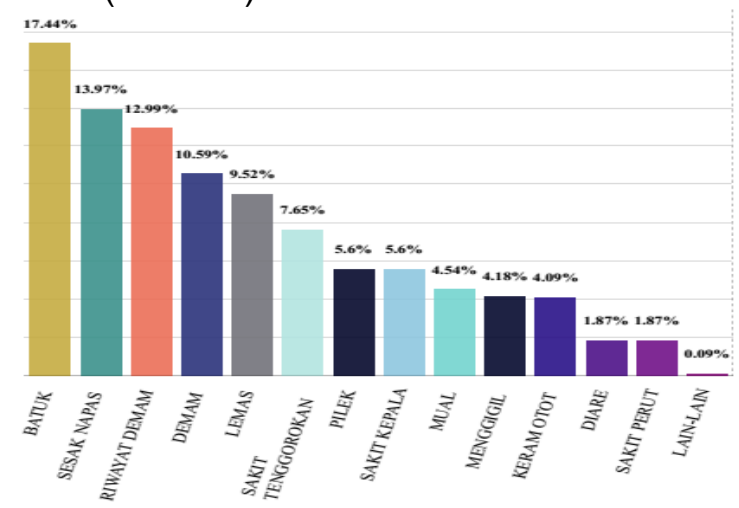

Figure 3. Signs and Symptoms of COVID-19 patients ${ }^{\underline{5}}$

Based on the signs and symptoms of COVID-19 in figure 3, many patients experience coughing, shortness of breath and a history of internal medicine and fever. Research that has been done shows signs and symptoms of fever (96\%) and cough (51.47\%) were the most 
common symptoms. ${ }^{23}$ Coronavirus infection in Indonesia by sex is mostly experienced by men $(58.94 \%)$ while women $(41.06 \%) .{ }^{10}$

\section{Physical and Social Distancing Compliance}

The results of an online survey with Google form via the internet, Facebook, and WhatsApp related to community compliance with physical and social distancing calls, based on the results of the RI Ministry of Health Research and Development briefing policy of 19,654 samples, $99.96 \%$ knew about the government's recommendations for physical distancing. However, only $54.29 \%$ were obeyed keep distance and $8.82 \%$ stay at home, $32.09 \%$ stated that leaving the house to shop for basic needs, $43.99 \%$ stated leaving the house for urgent needs. from 19,654 respondents who carried out the health protocol, $93.40 \%$ used masks, $17.20 \%$ wore gloves, $47.37 \%$ said they always brought a hand sanitizer, and $31.79 \%$ said they gave greetings without contact. ${ }^{24}$

Activities that are still a concern in the results of the compliance survey are outdoor activities. This cannot be denied because the community needs to fulfil their daily needs, besides the policy taken by the government by implementing Large Scale Social Restrictions (PSBB) which it is still considered loose not applying total lockdown so that people are free to leave the house.

\section{Prevention and Control of COVID-19 Spread}

Public health and control measures are needed to reduce the transmission of COVID19 people to people by limiting the global spread of the virus. ${ }^{22}$ Experience from the early phase of SARS-CoV-2 Pneumonia strongly highlighted that travel history, rather than chest radiography, is of paramount importance for early detection and isolation of SARS-CoV-2 pneumonia cases. ${ }^{24}$ Public services and facilities must provide antiseptic reagents for regular hand washing WHO recommends that it is crucial to limit transmission of infection by Physical distancing to avoid close contact, especially with health care workers and to prevent international outbreaks of avoiding countries or regions of the red zone. In addition, people with symptoms of respiratory tract infections should practice cough etiquette, which is to keep a distance, cover the cough and sneeze with disposable tissues or clothing, and wash hands, and in health care facilities improve infection prevention standards and control practices. especially in the emergency department. ${ }^{4}$

The Ministry of Health of the Republic of Indonesia issued Regulation No. 9 of 2020 concerning Large-Scale Social Restriction Guidelines. Some activities are limited as long as the regions carry out the Large-Scale Social Restrictionincluding restrictions on schools, work at the office, religious activities, public facilities, social culture, public transportation and defence and security. Efforts that are no less important are guarding public panic, social media one-sidedly increases knowledge and understanding, but also has the potential to spread false information or false news. Therefore the government needs to provide accurate knowledge and prevent hoax information. It is also necessary to make efforts by all components of the community by exploring the potential of the community to be empowered and able to play a role in preventing the transmission of Covid-19.

\section{CONCLUSION}

The COVID-19 outbreak has become a health threat worldwide, Indonesia is one of the countries affected by more than 9,000 cases, and more than 784 people have died. Epidemiologically the COVID-19 case in Indonesia occurred in the 34 highest provinces in Jakarta, most patients were aged 30-49 years, male sex and many were accompanied by comorbid hypertension, DM and heart disease. Efforts to reduce Covid-19 cases by implementing health, social and physical distancing protocols through the Large Scale Social Restrictions policy.

\section{DISCLOSURE STATEMENT}

The authors declare that they have no conflict of interest. 


\section{ACKNOWLEDGEMENT}

All the authors acknowledge and thank their respective Institutes, Task Force for the Acceleration of Handling COVID-19 Ministry of Health of the Indonesian government, which has provided COVID-19 update data.

\section{FUNDING INFORMATION}

The authors declared that this case had received no financial support.

\section{REFERENCES}

1. Lu H, Stratton CW, Tang Y. Outbreak of pneumonia of unknown etiology in Wuhan, China: The mystery and the miracle. J Med Virol. 2020;92(4):401-402. doi:10.1002/imv.25678

2. Guan W, Ni Z, Hu Y, et al. Clinical Characteristics of Coronavirus Disease 2019 in China. N Engl J Med. 2020;382(18):1708-1720. doi:10.1056/NEJMoa2002032

3. Sun P, Qie S, Liu Z, Ren J, Li K, Xi J. Clinical characteristics of hospitalized patients with SARS-CoV-2 infection: A single arm meta-analysis. J Med Virol. 2020;92(6):612617. doi:10.1002/jmv.25735

4. WHO. Coronavirus disease (COVID-19) Situationreport. Coronavirus disease. https://www.who.int/emergencies/diseases/novel-coronavirus-2019/situation-reports/. Published 2020.

5. Gugus Penanganan COVID-19. Peta Sebaran. Gugus Tugas Percepatan Penanganan COVID 19. https://covid19.go.id/peta-sebaran. Published 2020.

6. Wu A, Peng Y, Huang B, et al. Genome Composition and Divergence of the Novel Coronavirus (2019-nCoV) Originating in China. Cell Host Microbe. 2020;27(3):325-328. doi:10.1016/..chom.2020.02.001

7. Malik YS, Sircar S, Bhat S, et al. Emerging novel coronavirus (2019-nCoV)—current scenario, evolutionary perspective based on genome analysis and recent developments. Vet Q. 2020;40(1):68-76. doi:10.1080/01652176.2020.1727993

8. Rothe C, Schunk M, Sothmann P, et al. Transmission of 2019-nCoV Infection from an Asymptomatic Contact in Germany. N Engl J Med. 2020;382(10):970-971. doi:10.1056/NEJMc2001468

9. Chan JF-W, Yuan S, Kok K, et al. A familial cluster of pneumonia associated with the 2019 novel coronavirus indicating person-to-person transmission: a study of a family cluster. Lancet. 2020;395(10223):514-523. doi:10.1016/S0140-6736(20)30154-9

10. Erlina Burhan, Fathiyah Isbaniah, Agus Dwi Susanto, Tjandra Yoga Aditama, Soedarsono, Teguh Rahayu Sartono, Yani Jane Sugiri, Rezki Tantular, Bintang YM Sinaga, R.R Diah Handayani HA. Pneumonia Dan COVID-19. Perhimpunan Dokter Paru Indonesia Indonesia; 2020. https://www.persi.or.id/images/2020/data/buku pneumonia covid19.

11. Huang C, Wang Y, Li X, et al. Clinical features of patients infected with 2019 novel coronavirus in Wuhan, China. Lancet. 2020;395(10223):497-506. doi: 10.1016/S01406736(20)30183-5

12. Wang D, Hu B, Hu C, et al. Clinical Characteristics of 138 Hospitalized Patients With 2019 Novel Coronavirus-Infected Pneumonia in Wuhan, China. JAMA. 2020;323(11):1061. doi:10.1001/jama.2020.1585

13. Maier HJ, Bickerton E, Britton P. Coronaviruses. Vol 1282. (Maier HJ, Bickerton E, Britton P, eds.). New York, NY: Springer New York; 2015. doi:10.1007/978-1-49392438-7

14. Li J, You Z, Wang Q, et al. The epidemic of 2019-novel-coronavirus (2019-nCoV) pneumonia and insights for emerging infectious diseases in the future. Microbes Infect. 2020;22(2):80-85. doi:10.1016/i.micinf.2020.02.002

15. Yang J, Zheng Y, Gou X, et al. Prevalence of comorbidities and its effects in patients infected with SARS-CoV-2: a systematic review and meta-analysis. Int $J$ Infect Dis. 2020;94:91-95. doi:10.1016/j.jijid.2020.03.017 
16. Dhama K, Patel SK, Pathak M, et al. An update on SARS-CoV-2/COVID-19 with particular reference to its clinical pathology, pathogenesis, immunopathology and mitigation strategies. Travel Med Infect Dis. 2020;(March):101755. doi:10.1016/j.tmaid.2020.101755

17. $\mathrm{Xu}$ Y, Dong J, An W, et al. Clinical and computed tomographic imaging features of novel coronavirus pneumonia caused by SARS-CoV-2. J Infect. 2020;80(4):394-400. doi:10.1016/i.jinf.2020.02.017

18. Pan $\mathrm{F}, \mathrm{Ye} \mathrm{T}$, Sun $\mathrm{P}$, et al. Time course of lung changes at chest $\mathrm{CT}$ during recovery from Coronavirus disease 2019 (COVID-19). Radiology. 2020;295(3):715-721. doi:10.1148/radiol.2020200370

19. Culp WC. Coronavirus Disease 2019. A A Pract. 2020;14(6):e01218. doi:10.1213/XAA.0000000000001218

20. Stang A, Standl F, Jöckel KH. Characteristics of COVID-19 pandemic and public health consequences. Herz. 2020;45(4):313-315. doi:10.1007/s00059-020-04932-0

21. Wang F-S, Zhang C. What to do next to control the 2019-nCoV epidemic? Lancet. 2020;395(10222):391-393. doi:10.1016/S0140-6736(20)30300-7

22. Biscayart C, Angeleri P, Lloveras S, Chaves T do SS, Schlagenhauf P, RodríguezMorales AJ. The next big threat to global health? 2019 novel coronavirus (2019-nCoV): What advice can we give to travellers? - Interim recommendations January 2020, from the Latin-American society for Travel Medicine (SLAMVI). Travel Med Infect Dis. 2020;33(January):101567. doi:10.1016/i.tmaid.2020.101567

23. Song F, Shi N, Shan F, et al. Emerging 2019 Novel Coronavirus (2019-nCoV) Pneumonia. Radiology. 2020;295(1):210-217. doi:10.1148/radiol.2020200274

24. Kim JY, Choe PG, Oh Y, et al. The First Case of 2019 Novel Coronavirus Pneumonia Imported into Korea from Wuhan, China: Implication for Infection Prevention and Control Measures. J Korean Med Sci. 2020;35(5):1-4. doi:10.3346/jkms.2020.35.e61

\section{SHORT BIOGRAPHY}

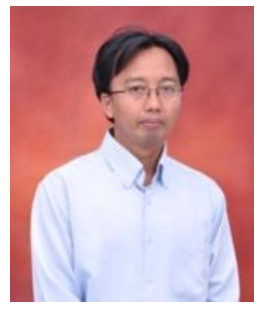

Sutaryono. He graduated from the Diponegoro University Semarang in 2009 as Master of Epidemiology. He is post-doc in specialization of environmental health at Sebelas Maret University Surakarta in 2019. He has been working as a Lecturer / Assistant Professor and researcher at the Department of Pharmacy, STIKES Muhammadiyah Klaten, Indonesia since 2003.

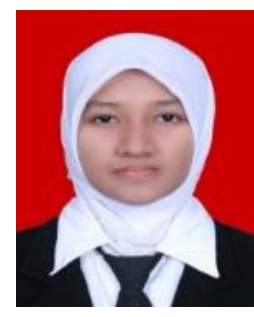

Sholikhah Deti Andasari. She is a Master of Pharmacy from the Muhammadiyah University of Surakarta in 2017. She has been a researcher and Lecturer at the Department of Pharmacy, STIKES Muhammadiyah Klaten, Indonesia since 2013. Her current research looks at the problems or issues related to the Pharmaceutical sciences.

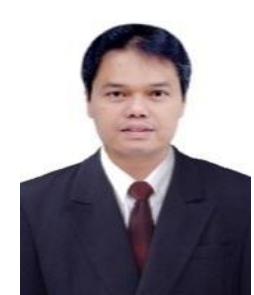

Heru Subaris Kasjono. Alumni APK-TS of the Yogyakarta Health Department (graduated in 1988) and He has been working as a Lecturer/Associate Professor in the Politeknik Kesehatan Kementerian Kesehatan RI Yogyakarta, Indonesia. Bachelor of public health at Faculty of Public Health-Indonesia University (1995), Post graduate of Clinical Epidemiology at Faculty of Clinical Medicine, Gadjah Mada University (2003), Doctor of Counseling Development Program / Community Empowerment Main Interest in Health Promotion at Sebelas Maret University (2016). 